\title{
The Relation between Renewable Energy Consumption and Economic Growth: The Case of 3 Mediterranean Countries
}

\section{La relación entre el consumo de energías renovables y el crecimiento económico: El caso de 3 países mediterráneos}

DOI: $10.46932 / s f j d v 2 n 4-061$

Received in: May 1st, 2021

Accepted in: Jun 30th, 2021

\author{
Majd Allam \\ $\mathrm{PhD}$ in Energy and Environment \\ Sapienza - University of Rome, Italy \\ E-mail:majd.allam@uniroma1.it \\ Raymond Bou Nader \\ $\mathrm{PhD}$ in Business Statistics \\ E-mail: raymond.bounader@usj.edu.lb
}

Institute of business administration (IGE) Saint Joseph University - Beirut, Lebanon

\begin{abstract}
The purpose of this study is to investigate the relationship between renewable energy and economic growth which is determined by the gross domestic product per capita regarding some of the Mediterranean countries. This study uses data from some Mediterranean countries with medium to high energy consumption levels in 1990-2015 (France, Italy, and Turkey) to ascertain and analyze the multiple effects of renewable energy consumption on economic process. The applied math analysis relies on descriptive statistics, cluster analysis, and divulges that all the variables area unit are related; this means, on the long term, a correlation between the dependent variable quantity of gross domestic product and the independents variables of renewable energy consumption and energy consumption. Moreover, the results show that there's a better correlation between RES' consumption and the economic growth of some countries that has an upper gross domestic product than with those of lower GDP. The obtained results area unit is consistent with different papers reviewed during this study. Analysis results show the long run linear impact of energy consumption on economic process.
\end{abstract}

Keywords: Renewable Energy, Economic Growth, GDP, Energy consumption

\section{RESUMEN}

El objetivo de este estudio es investigar la relación entre las energías renovables y el crecimiento económico, que viene determinado por el producto interior bruto per cápita, en relación con algunos de los países mediterráneos. Este estudio utiliza datos de algunos países mediterráneos con niveles de consumo de energía medios y altos en 1990-2015 (Francia, Italia y Turquía) para conocer y analizar los múltiples efectos del consumo de energías renovables en el proceso económico. El análisis matemático aplicado se basa en la estadística descriptiva y el análisis de conglomerados, y divulga que todas las variables están relacionadas; esto significa que, a largo plazo, existe una correlación entre la variable dependiente cantidad de producto interior bruto y las variables independientes consumo de energía renovable y consumo de energía. Además, los resultados muestran que hay una mejor correlación entre el consumo de FER y el crecimiento económico de algunos países que tienen un producto interior bruto superior que con los de menor PIB. Los resultados obtenidos son coherentes con diferentes trabajos 
revisados durante este estudio. Los resultados del análisis muestran el impacto lineal a largo plazo del consumo de energía en el proceso económico.

Palabras clave: Energías renovables, crecimiento económico, PIB, consumo de energía

\section{INTRODUCTION}

The subject of the study is in line with the objectives set by the leaders of Euro-Mediterranean countries within the 2030 Agenda for Sustainable Development 1 geared toward reducing the energy consumption and achieving an identical share of renewable energy within the final energy consumption. Thus, increasing energy potential, ought to result in lower energy demand per unit of value within the economy, a cut of gas emissions and the identification of long-term solutions to cut back the dependence on fossil fuel energy sources. The enhanced energy prices alongside the strategic goals undertaken globally, within the space of pollution reduction, have contributed to a lot of elaborated study between renewable energy consumption and the economic process. In several Mediterranean economies, many measures have been taken towards the energy consumption: cut back pollution by reducing the using of energy and stimulating the economic activity. In general, the industrial sector of a country is more energy intensive compared to the service sector, thus the service sector increases economic growth in the context of a relatively lower energy consumption. Under these circumstances, the more developed Mediterranean countries' economies, with a lower proportion of industry will enjoy a reduced energy consumption per GDP unit. This research shows the link between economic growth and the energy consumption. Data concerning 3 Mediterranean countries for the period 1990-2015 is statistically analyzed. Our main objective is to find whether there is interaction between these variables, and whether this correlation is affected when a country has a high GDP rate.

\section{LITERATURE REVIEW}

In recent years, the renewable energy area has continued to create jobs, whereas the conventional power sector has struggled to continue them. IRENA's analysis 2 finds that the sector should rent around 25 million people worldwide. In the US, the solar PV area introduced workers nearly 17 instances as fast as the ordinary economy throughout 2016 (Solar Foundation, 2017). Rising automation, overcapacities, enterprise consolidation and shifts closer to cleaner electricity are ensuing in job losses in the fossil-fuel sector. China is making ready for the layoff of 1.3 million coal miners (Yan, 2016); India's greatest coal organization has shed $36 \%$ of its employees on account that 2002/03 (Statista, 2017); and the coal industry group of workers in Europe and North America has been shrinking for many years. The global oil and gas 
industry are also confronting job losses due to low oil prices and oversupply, with at least 440000 people laid off in 2015 and 2016 (Jones, 2017).

Many studies show that 'renewable energy sources' is the solution to tackle climate change and energy security issues. The developed model in the research they did, Apergis and Payne, showed a casual relation between RES consumption and GDP, in the short and long term. Add to this the relationship between non-renewable forms of energy, concluding that there is feasibility in swapping between energy forms.

We can see this link between RES and economic growth in other publications with different countries. Also, we can find a positive relation between RES and promoting economic growth. According to Al-Mulali et al., Renewable energy sources are mandatory because it minimize the environmental impacts plus it gives the energy security every country ought to have.

\section{EMPIRICAL ANALYSIS}

\subsection{DATA AND MODEL}

During the period 1990-2015 data for 3 developing MED countries, real gross domestic product (GDP) in billions of constant 2010 U.S dollars, total energy consumption (EP) and renewable energy consumption (RE) that is defined in the share of renewable energy in total final energy consumption were obtained from the World Bank Data.

The developed empirical model we used for examining long-run effect of renewable energy on economic growth is written as (Apergis, 2014) ${ }^{1}$ :

$$
G D P_{i t}=\beta_{0}+\beta_{1} R E_{i t}+\beta_{2} E P_{i t}+\epsilon_{i t}
$$

Where, $\mathrm{i}=1, \ldots, \mathrm{N}$ denotes each country and $\mathrm{t}=1, \ldots, \mathrm{T}$ refers to the time period.

The parameter $\beta 0$ allows for the possibility of country specific fixed effects. To perform the availability of the long-run equilibrium, a cointegration test is applied on residuals using the procedure of Engle and Granger ${ }^{2}, 1987$.

\footnotetext{
${ }^{1}$ Apergis, N.; Danuletiu D. C. Renewable Energy and Economic Growth: Evidence from the Sign of Panel Long-Run Causality. Energy Econ. Vol. 4, No. 4, 2014, pp.578-587.

2 Engle, R. F. and C. W. J. Granger. "Co-Integration and Error-Correction: Representation, Estimation, and Testing." Econometrica. v. 55, 1987, pp. 251-276.
} 


\subsection{EMPIRICAL FINDINGS}

To examine RES' consumption correlation with countries' economic process, Word bank's latest dataset regarding 3 MED countries between 1990 and 2015 is used. Due to the risk of different measurement methodology that can lead to biased results, other data sources, such as OECD or IEA data, are not inserted into our dataset. The cointegration is a common methodology proposed in similar studies for the long-run impact. The model is developed in MATLAB and will lead to reflect the impact of energy production and renewable energy on GDP at the long-run equilibrium.

\subsection{DESCRIPTIVE ANALYSIS}

The below graphs show a positive relationship between electricity production and GDP for the three countries. The renewable energy has a positive correlation with GDP from France and Italy whereas for Turkey the renewable energy is decreasing with the time due to political turbulence. Therefore, the renewable energy factor is omitted from Turkey analysis.

Figure 1. Correlation between GDP and RE \& EP in France

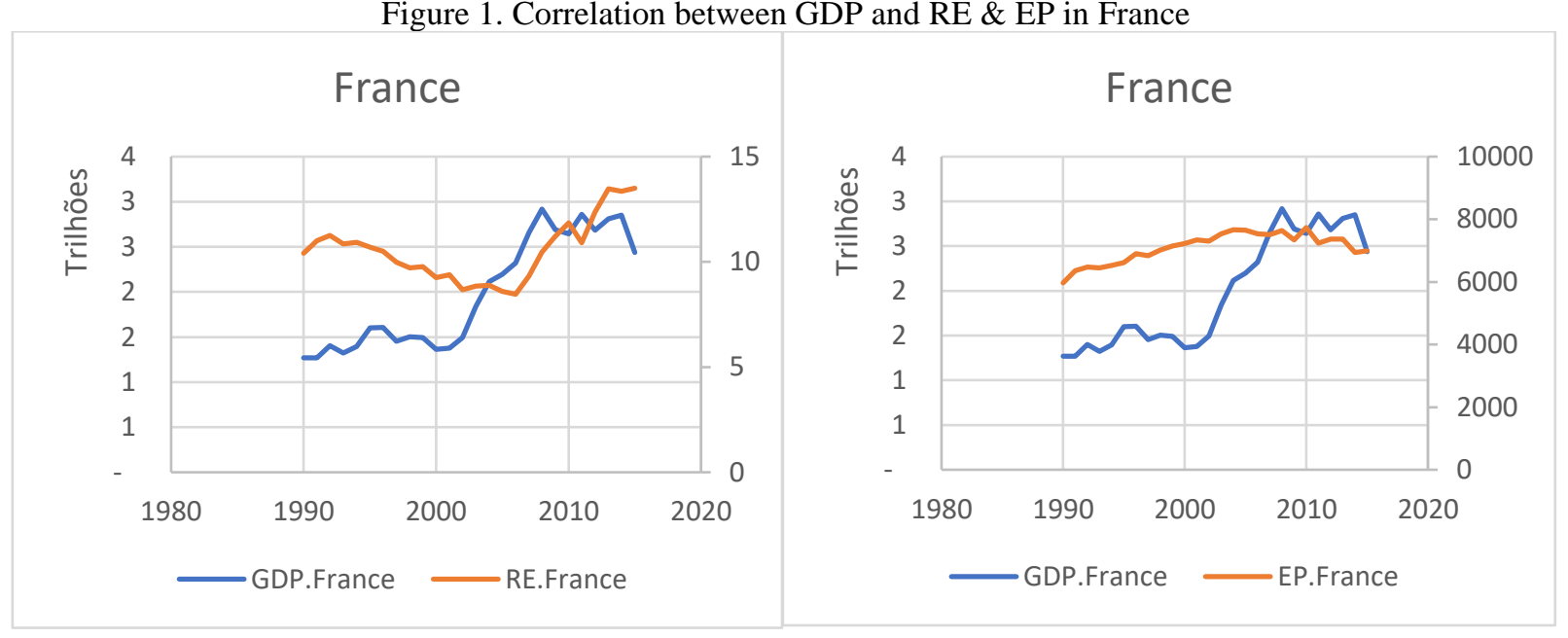

Figure 2. Correlation between GDP and RE \& EP in Italy
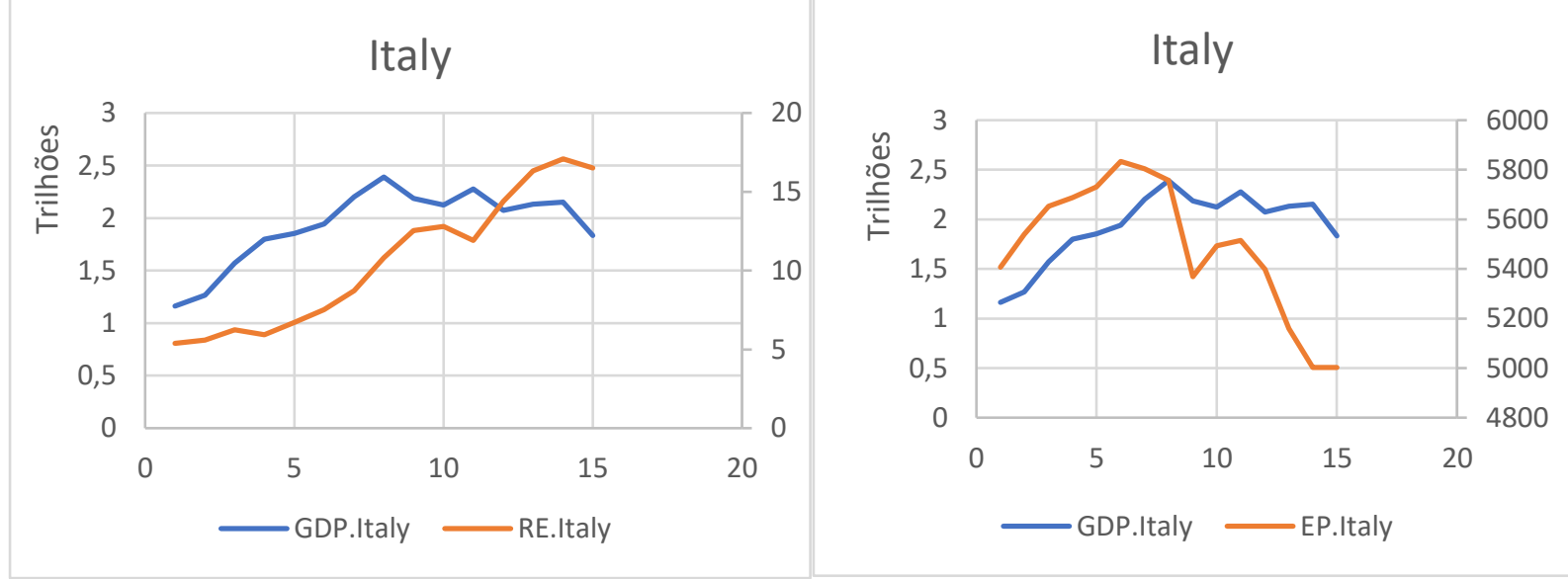
Figure 3. Correlation between GDP and RE \& EP in Turkey

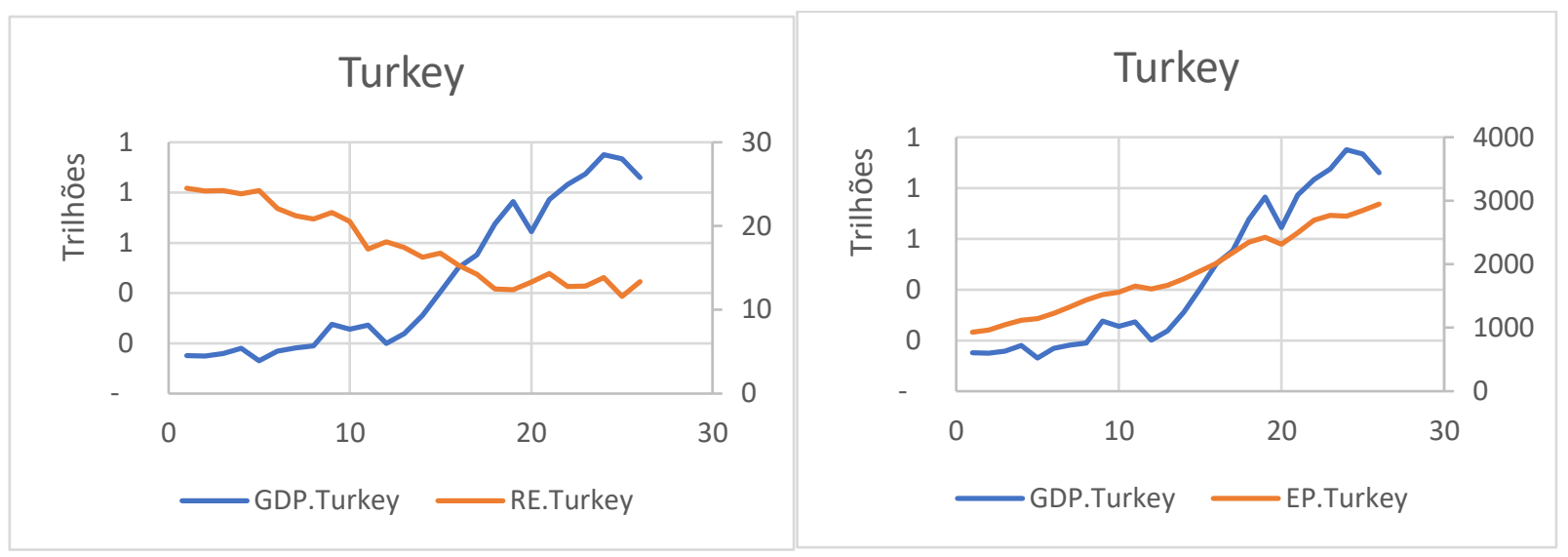

\subsection{PARAMETER ESTIMATION}

Figure 4. Gross domestic product estimation for France with a $1 \%$ fluctuation of RE \& energy consumption

1. Augmented Dickey Fuller Test

\begin{tabular}{|lrrl|}
\hline Variable & \multicolumn{1}{c}{ T-Stat } & \multicolumn{1}{l}{ P-Value } & Result \\
\hline GDP & 0.9137 & 0.8979 & Non-Stationary \\
$\Delta$ GDP & -3.3663 & 0.0023 & Stationary \\
\hline RE & 1.0122 & 0.9127 & Non-Stationary \\
$\Delta$ RE & -4.0673 & 0.0001 & Stationary \\
\hline EP & 0.7871 & 0.8764 & Non-Stationary \\
$\Delta$ EP & -7.1169 & 0.0001 & Stationary \\
\hline
\end{tabular}

2. Cointegration (Engle Granger Procedure)

\begin{tabular}{|lr|}
\hline Tstat & -3.6406 \\
P Value & 0.1107 \\
\hline
\end{tabular}

$G D P_{t}=a_{0}+a_{1} R E+b_{1} E P+\epsilon_{t}$

\begin{tabular}{|c|c|c|c|}
\hline & Estimate & Tstat & Pvalue \\
\hline $\mathrm{aO}$ & $-8 \mathrm{E}+12$ & -6.431982754 & 1.46E-06 \\
\hline a1 & $2.55 E+11$ & 5.575668686 & $1.13 \mathrm{E}-05$ \\
\hline b1 & $1.02 \mathrm{E}+09$ & 7.097243624 & $3.14 \mathrm{E}-07$ \\
\hline & Estimate & Tstat & Pvalue \\
\hline$\alpha$ & 0.3302 & 1.7949 & 0.0853 \\
\hline
\end{tabular}

3. Sensitivity Analysis

\begin{tabular}{|c|c|c|}
\hline & Change & Implied GDP Growth \\
\hline EP & $1 \%$ & $2.93 \%$ \\
\hline RE & $1 \%$ & $10.44 \%$ \\
\hline
\end{tabular}




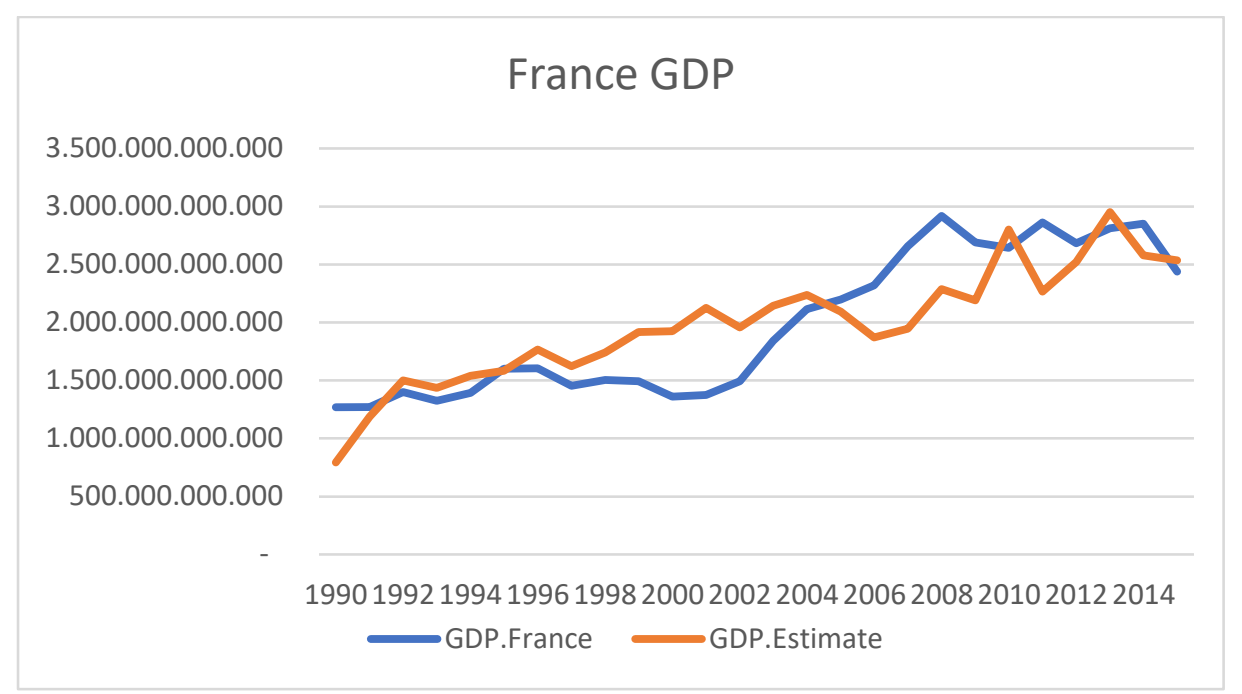

Figure 5. Gross domestic product estimation for Italy with a 1\% fluctuation of RE \& energy consumption

1. Augmented Dickey Fuller Test

\begin{tabular}{|lrrl|}
\hline Variable & \multicolumn{1}{l}{ T-Stat } & P-Value & Result \\
\hline GDP & 0.5399 & 0.819 & Non-Stationary \\
$\Delta$ GDP & -2.3168 & 0.0243 & Stationary \\
\hline RE & 2.543 & 0.9939 & Non-Stationary \\
$\Delta R E$ & -1.9444 & 0.0513 & Stationary \\
\hline EP & -0.7205 & 0.3708 & Non-Stationary \\
$\Delta$ EP & -2.9551 & 0.0068 & Stationary \\
\hline
\end{tabular}

2. Cointegration (Engle Granger Procedure)

\begin{tabular}{|lr|}
\hline Tstat & -5.1539 \\
P Value & 0.0146 \\
\hline
\end{tabular}

\begin{tabular}{|llrrr|}
\hline & Estimate & Tstat & \multicolumn{2}{c|}{ Pvalue } \\
a0 & $-7.5 \mathrm{E}+12$ & -6.396435049 & $3.42 \mathrm{E}-05$ \\
a1 & $1.24 \mathrm{E}+11$ & 10.0292125 & $3.47 \mathrm{E}-07$ \\
b1 & $1.48 \mathrm{E}+09$ & 7.595932587 & $6.37 \mathrm{E}-06$ \\
\hline
\end{tabular}

\begin{tabular}{|rrrr|}
\hline & Estimate & Tstat & \multicolumn{2}{c|}{ Pvalue } \\
& - & & \\
$\alpha$ & 0.37844 & -1.415 & 0.1806 \\
\hline
\end{tabular}

3. Sensitivity Analysis

\begin{tabular}{|c|c|c|}
\hline & Change & Implied GDP Growth \\
\hline EP & $1 \%$ & $4.04 \%$ \\
\hline $\mathrm{RE}$ & $1 \%$ & $6.77 \%$ \\
\hline
\end{tabular}




\section{Italy GDP}

$3 \mathrm{E}+12$

$2.5 \mathrm{E}+12$

$2 \mathrm{E}+12$

$1.5 \mathrm{E}+12$

$1 \mathrm{E}+12$

$5 \mathrm{E}+11$

0

200120022003200420052006200720082009201020112012201320142015

GDP.Italy GDP.Estimate

Figure 6. Gross domestic product estimation for Turkey with a $1 \%$ fluctuation of RE \& energy consumption

1. Augmented Dickey Fuller Test

\begin{tabular}{|lrrl|}
\hline Variable & \multicolumn{1}{l}{ T-Stat } & \multicolumn{1}{l}{ P-Value } & Result \\
\hline GDP & 1.7831 & 0.9786 & Non-Stationary \\
$\Delta$ GDP & -3.8697 & $1.00 \mathrm{E}-03$ & Stationary \\
\hline EP & 5.5239 & 0.999 & Non-Stationary \\
$\Delta$ EP & -2.2295 & 0.0273 & Stationary \\
\hline
\end{tabular}

Cointegration (Engle Granger Procedure)

\begin{tabular}{|lr|}
\hline Tstat & -2.2259 \\
P Value & 0.4452 \\
\hline
\end{tabular}

No Cointegration $=>$ Autoregressive Model

\begin{tabular}{|lrrrr|}
\hline & Estimate & Tstat & \multicolumn{2}{c|}{ Pvalue } \\
alpha & $4.6 \mathrm{E}+08$ & & 4.893231831 & $5.45 \mathrm{E}-05$
\end{tabular}

Sensitivity Analysis

3.

\begin{tabular}{|c|c|c|}
\hline & Change & Implied GDP Growth \\
\hline EP & $1 \%$ & $1.58 \%$ \\
\hline
\end{tabular}




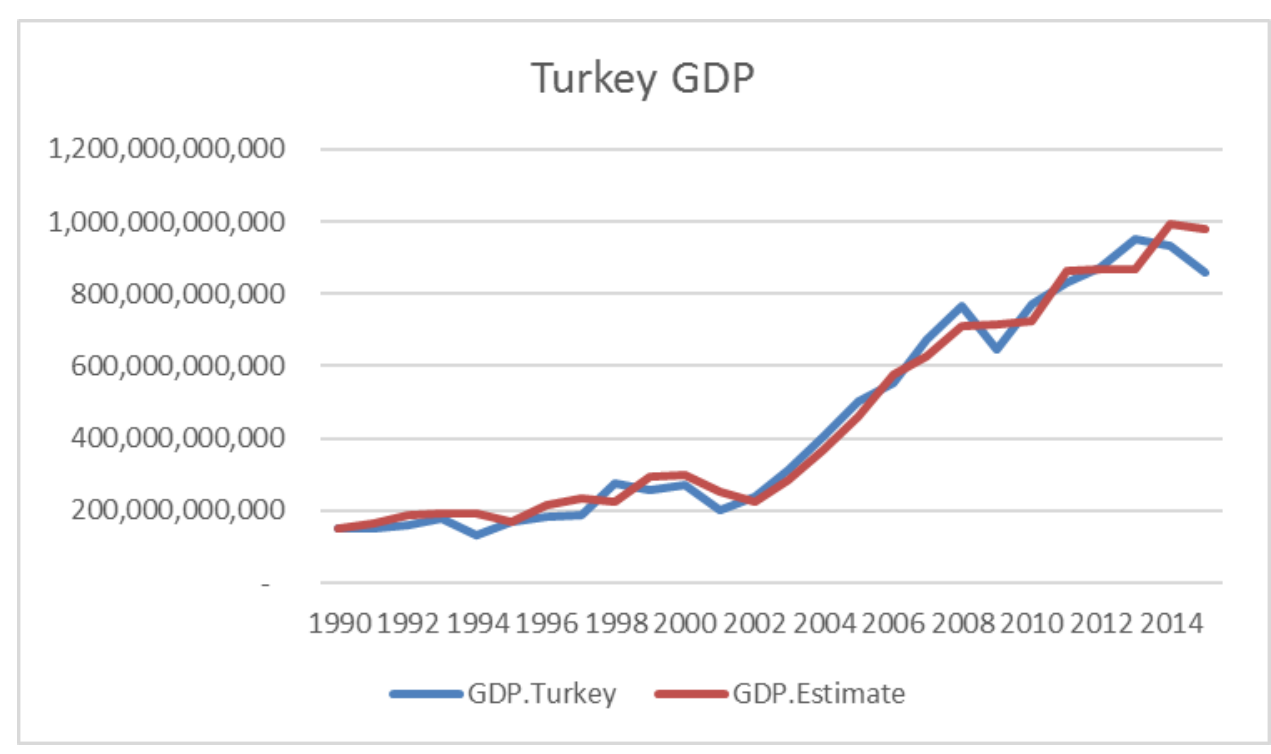

Results:

The model is developed in MATLAB and reflect the impact of energy production and renewable energy on GDP at the long-run equilibrium.

In France, at an accuracy rate of $92 \%$, an increase of $1 \%$ fluctuation in renewable energy in total final energy consumption led to $10.44 \%$ increase in the GDP Growth of France.

In Italy, at an accuracy rate of $83 \%$, an increase of $1 \%$ fluctuation in renewable energy in total final energy consumption led to $6.77 \%$ increase in the GDP Growth of Italy.

In Turkey, at an accuracy rate of $97 \%$, an increase of $1 \%$ fluctuation in total energy production led to $1.58 \%$ increase in the GDP Growth of Turkey.

\section{CONCLUSION}

On one hand, the transformation of latest energy consumption can often bring economic costs, thereby leading to a negative impact on economic process. On the opposite hand, economic value often disappears, thereby leading to the positive impact of the transformation of latest energy consumption on economic process.

The results of the study can be summarized as follows:

Renewable energy contributes effectively to achieving sustainable development. Its exploitation by humans does not have any negative impact on the environment and this contributes to its preservation, which confirms the basic premise. Countries with a high level of human development are also among the countries that use the most renewable energy, compared to those with less use. There is a direct relationship between each of the GDP and renewable energy consumption (REC). Where the increase in 
renewable energy consumption by $1 \%$ led to an increase of GDP by $10 \%$ in France, as well as reflect the value of p.value which is 0.92 for the significance of the relationship between the two variables.

A quantity of factors has an impact on the GDP growth estimated in this study, such as investment in renewable strength deployment, fossil fuel production and trade, and electrical energy prices. Investments particularly influence GDP growth the foremost, triggered by the capital-intensive nature of renewable energy technologies compared to different choices. Most of the complete fee of renewable energy plants is used for the upfront funding on physical assets, as hostile to gasoline expenditure throughout the lifecycle of the plant. As the demand for electricity grows, proportionate investments in strength infrastructure will be needed. To keep away from lock-in with unsustainable energy systems, and recognize the potential benefits, energy sector investments should increasingly be directed towards renewable energy. Investment in renewable energy throughout all sectors must be scaled up substantially. The power region will proceed to attract most of the new investment. This report estimates the GDP based on renewable energy consumption for each of the 3 cases; as nicely as the capital costs, discount rates and different parameters required for every technology in each country and year to be able to achieve the growth needed. 


\section{REFERENCES}

Apergis, N., Payne, J.E. (2010). The renewable energy consumption-growth nexus in Central America, Applied Energy, 88, 343-347.

Apergis, N., Payne, J.E. (2012). The electricity consumption-growth nexus: Renewable versus nonrenewable electricity in Central America, Energy Sources, Part B: Economics, Planning, and Policy, 7, 423-431.

Bowden, N., Payne, J.E. (2010). Sectoral analysis of the causal relationship between renewable and nonrenewable energy consumption and real output in the U.S., Energy Sources, Part B: Economics, Planning, and Policy, 5, 400408.

Canning, D., Pedroni, P. (2008). Infrastructure, long-run economic growth and causality tests for cointegrated panels, The Manchester School, 76, 504-527.

EC (European Commission) and ILO (International Labour Organization) (2011), Skills and Occupational Needs in Renewable Energy, Geneva

Engle, R. F. and C. W. J. Granger. "Co-Integration and Error-Correction: Representation, Estimation, and Testing.” Econometrica. v. 55, 1987, pp. 251-276.

Esso, J.L. (2010). The energy consumption-growth nexus on seven Sub-Sahara African countries, IEA (2009). World Energy Outlook. International Energy Agency. Paris, France.

Im, K.S., Pesaran, M.H., Shin, Y. (2003). Testing for unit roots in heterogeneous panels, Journal of Econometrics, 115, 53-74.

IRENA (2018b forthcoming), Realising Community Benefits of Large-Scale Renewable Energy Deployment: Insights from Sub-Saharan African Countries.

Kaygusuz, K. (2007). Energy for sustainable development: Key issues and challenges, Energy Sources, Part B: Economics, Planning, and Policy, 2, 73-83.

Lean, H.H., Smyth, R. (2013). Disaggregated energy demand by fuel type and economic growth in Malaysia, Discussion Paper, No. 43-13, Department of Economics, Monash University.

Leitao, N.C. (2014). Economic growth, carbon dioxide emissions, renewable energy and globalization, International Journal of Energy Economics and Policy, 4, 391-299.

Pao, H.T., Fu, H.C. (2013), The causal relationship between energy resources and economic growth in Brazil. Energy Policy, 61, 793-801.

Payne, J.E. (2010), Survey of the international evidence on the causal relationship between energy consumption and growth. Journal of Economic Studies, 37, 53-95

Pirlogea, C., Cicea C. (2012), Econometric perspective of the energy consumption and economic growth relation in European Union, Renewable and Sustainable Energy Reviews, 16, 5718-5726.

Stren, D. (1993), Energy and economic growth in the USA, A multivariate approach, Energy Economics, 
15(2), 137-150.

\section{BIOGRAPHIES}

Allam M. holds a Bachelor of Science degree in Economics from Saint Joseph University, a Master of International Cooperation and Development in Political Science from La Sapienza University of Rome and a PhD in Energy and Environment from La Sapienza University of Rome. Worked in different financial institutions and banks.

BOU NADER R. is a statistician. He is an assistant professor at Saint Joseph University of Beirut, where he lectures in statistics and quantitative data analysis. He is a statistician consultant at the Center for Educational Research and Development (CERD), Ministry of Education in Lebanon, as well as an affiliated statistician at the IAPS laboratory of the University of Toulon (France) and at the Peel laboratory of the University of Lorraine (France) 